\title{
Coding signal strength by correlated activity in bursting neurons
}

\author{
Oscar Ávila Åkerberg ${ }^{1 *}$, Maurice J Chacron ${ }^{1,2}$ \\ From Nineteenth Annual Computational Neuroscience Meeting: CNS*2010 \\ San Antonio, TX, USA. 24-30 July 2010
}

Understanding how populations of neurons encode sensory information is of critical importance [1]. Correlations between the activities of neurons are ubiquitous in the central nervous system and, although their implications for encoding and decoding of sensory information has been the subject of arduous debates, there is a general consensus that their effects can be significant [2]. As such, there is great interest in understanding how correlated activity can be regulated. Recent experimental evidence has shown that correlated activity amongst pyramidal cells within the electrosensory lateral line lobe (ELL) of weakly electric fish can be regulated based on the behavioral context: these cells modulate their correlated activity depending on whether the fish is performing electrolocation or communication tasks without changing the mean firing rate of their response [3]. Moreover, it was shown in the same study that the changes in correlated activity were correlated with changes in bursting dynamics.

In this work we explore the role of intrinsic bursting dynamics on the correlated activity of ELL pyramidal neurons. We use a combination of mathematical modeling as well as in vivo and in vitro electrophysiology to show that bursting dynamics can significantly alter the

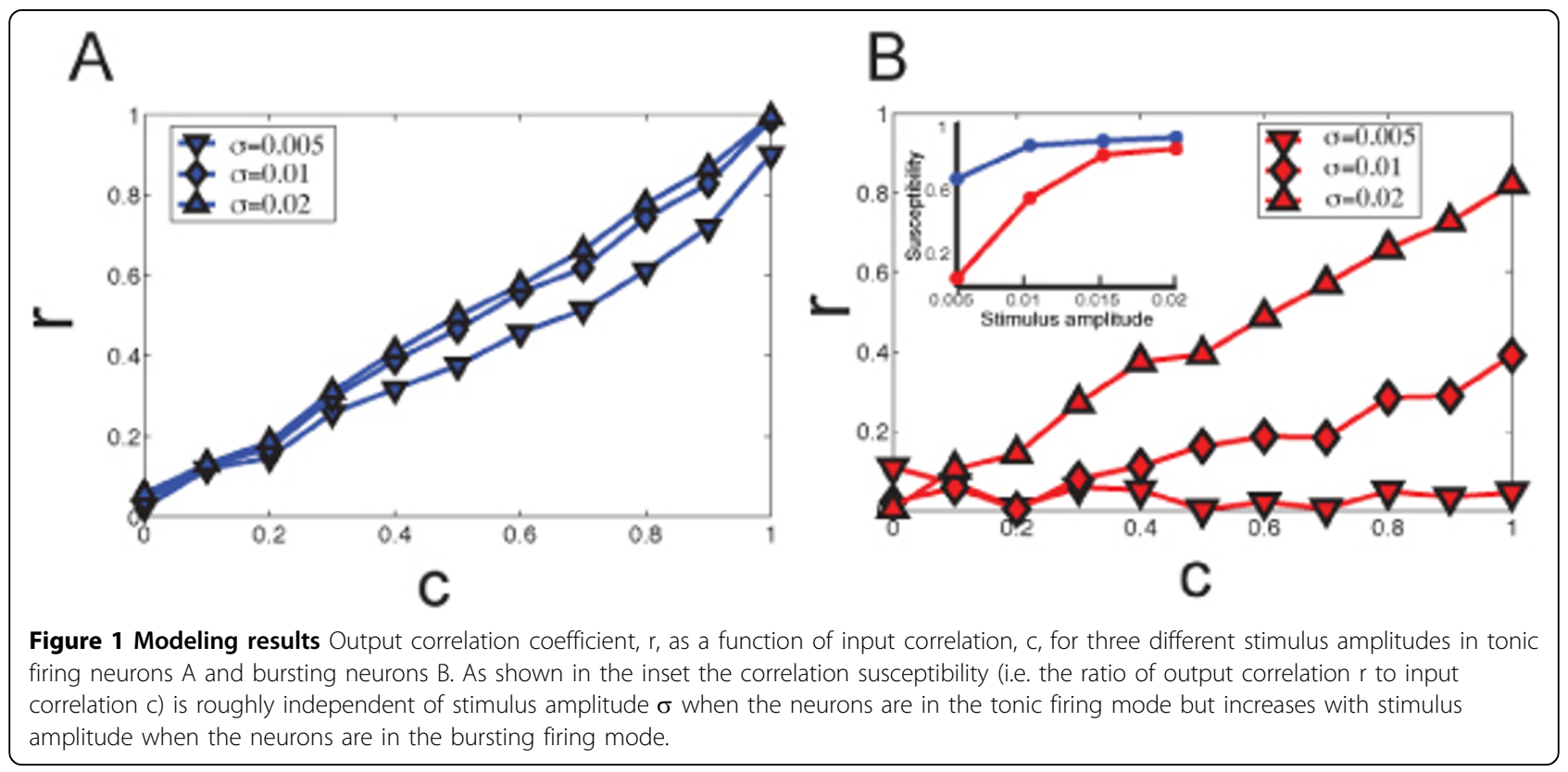

* Correspondence: oscar@cnd.mcgill.ca

'Department of Physics, McGill University, Montreal, Quebec, Canada, H3A2T8 
ability of neuronal populations to be correlated by common input. In particular, our model predicts that the ratio of output to input correlations (i.e. the correlation susceptibility [4]) is largely independent of stimulus amplitude when neurons are in the tonic firing model. In contrast, we find that the correlation susceptibility increases with stimulus amplitude when the neurons are in the bursting mode (Fig. 1). We then performed in vivo and in vitro experiments to verify this prediction. Our results show that intrinsic dynamics have important consequences on correlated activity and have further revealed a potential coding mechanism for stimulus amplitude through correlated activity.

\section{Author details}

'Department of Physics, McGill University, Montreal, Quebec, Canada, H3A2T8. 'Department of Physiology, McGill University, Montreal, Quebec, Canada, H3G1Y6.

Published: 20 July 2010

\section{References}

1. Averbeck BB, Latham PE, Pouget A: Neural correlations, population coding and computation. Nat. Rev. Neurosci 2006, 7:358-366.

2. Salinas E, Sejnowski TJ: Correlated neuronal activity and the flow of neural information. Nat. Rev. Neurosci 2001, 2(8):539-550.

3. Chacron MJ, Bastian J: Population coding by electrosensory neurons. J Neurophysiol 2008, 99(4):1825-1835.

4. Shea-Brown E, Josic K, de la Rocha J, Doiron B: Correlation and synchrony transfer in integrate-and-fire neurons: basic properties and consequences for coding. Phys Rev Lett 100(10):108102.

\section{Submit your next manuscript to BioMed Central} and take full advantage of:

- Convenient online submission

- Thorough peer review

- No space constraints or color figure charges

- Immediate publication on acceptance

- Inclusion in PubMed, CAS, Scopus and Google Scholar

- Research which is freely available for redistribution

Submit your manuscript at www.biomedcentral.com/submit 